\title{
The Effect of Fraud Pentagon and Academic Procrastination Dimensions Towards Academic Dishonesty of Students of Social Science in Senior High School of Semarang
}

\author{
Agung Yulianto ${ }^{1(*)}$, Luthfi Fathan Dahriyanto ${ }^{1}$, Rina Wijayanti ${ }^{1}$, Putri Adininggar ${ }^{1}$ \\ ${ }^{1}$ Universitas Negeri Semarang, Indonesia \\ *Corresponding author. Email: agungfe@mail.unnes.ac.id
}

\begin{abstract}
S
Academic dishonesty is a dishonest behavior done by students to obtain good marks by violating the regulations so that it harms other people. The effect of students' academic dishonesty is influenced by several factors such as academic pressure, opportunity, rationalization, individual's ability in making fraud, personal ethics, and academic procrastination. The objective of this esearch is to know the effect of fraud pentagon and academic procrastination dimensions towards academic dishonesty performed by Grade X Students of Social Sciences in Senior High School of Semarang. The population of this research is the Students of Social Sciences in Senior High School 8 of Semarang amounted to 180 students. The number of samples used are of 125 students that are counted by using Slovin formula. The sampling technique used is proportional random sampling. The data collection method is by using questionnaire method. In addition, the data analysis used is descriptive statistical analysis and multiple linear regression analysis. The result of descriptive analisis show that variabel of personal ethics is in high category, while academic dishonesty, academic pressure, opportunity, rationalization, individual's ability in making fraud, and academic procrastination in the high enough. The academic pressure, opportunity, rationalization, individual's ability in making fraud, personal ethics and academic procrastination simultaneously influenced the academic dishonesty. Whereas partially academic pressure, individual's ability in making fraud, and academic procrastination to influence positively. Opportunities and personal ethics negative influence while rasionalization does not effect. The suggestions given regarding this research's result are making a condition that does not make the students feel underpressure like not giving many assignments and making the students accustomed to being discipline, improving guidance and checking as well as applying stricter regulations regarding assignment completion and examination. Furthermore, it is better for students to improve their confidence on the academic ability that they have so that they can minimize the chance of academic dishonesty.

Keywords: Academic pressure, opportunity, rationalization, individual's ability in making fraud, academic
\end{abstract}

procrastination, personal ethics, academic dishonesty

\section{INTRODUCTION}

Character education can be integrated in to the learning process of each subject. Learning materials related to norms or values in each subject need to be developed, made explicit and related to the context of daily life. Thus, the learning of character values is not only given on the cognitive level, but also touches on internalization and real experiences so that it can be applied in everyday life at school and in society.

The Ministry of National Education (2011) [1] stated that "in order to further strengthen the implementation of character education in educational units, 18 values have been identified originating from religion, Pancasila, culture, and national education goals, namely religious, honest, tolerance, discipline, hard work, creative, independent, democratic, curiosity, national spirit, love of the motherland, respect for achievement, friendly / communicative, peace loving, love to read, environmental awareness, social awareness, and responsibility ". Honesty is one of the 18 values of character education that is important to shape the character of students. The development of student character can be in the form of internalizing honesty on every level of education to be able to be a preventive measure related to cheating. So that the level of academic fraud that occurs in the Indonesian education world will decrease and continue to decline until it reaches a relatively low level of academic fraud. 
But in reality, we still find many cheating practices in the world of education known as academic fraud. Academic fraud is cheating or dishonest behavior committed in an academic environment by using all means to obtain benefits for himself (Saidina, 2016) [2]. Yudiana \& Lastanti (2016) [21] academic fraud is an act committed by an individual or organization intentionally to deceive, conceal, or benefit in a condition where such actions can harm the parties concerned.

Research by Vinski and Tryon (2009) [3] in Utami (2014) of 109 student's New York's Riverhead High School, reported that the majority of them $(88 \%)$ cheated on exams. In addition, based on information obtained from tribunnews.com on Thursday 8 February 2018 said that there had been fraudulent act in the State of India during the exam, there were 500,000 students from grades 10 and 12 of high school and above being disqualified from administering the exam. They were disqualified after being caught cheating. Students in India assume that they will do a variety of ways to be able to commit fraud, namely cheating.

The phenomenon of academic fraud also occurs in the world of education in Indonesia. Wisnumurti \& Yulianto (2017) [4]in his research explained that academic fraud that is often committed by students is copy and paste from the internet while doing assignments $(72.5 \%)$, copying answers from other friends $(58.33 \%)$ and cooperating in quizzes $(57.5 \%)$. In addition, academic fraud cases reported by the mass media stated that the form of academic fraud in the national examination 2019 Kemendikbud received 202 complaints of fraud, where 126 fraud cases were verified and 76 cases of non-violation categories, three areas with the highest national cheating complaints is East Java Province with 21 cases, South Kalimantan Province with 18 cases, Bali Province with 15 cases (Republika.co.id)

Martindas (2010) [5] stated that academic fraud arises as an interaction of various factors, both internal (within the individual) and external (derived from the environment). Internal factors related to academic fraud include academic self-efficacy, academic achievement index, work ethic, self-esteem, ability or competence of academic motivation (need for approval belief), attitude, level of education, learning techniques (study skills) and morality. In addition, external factors include supervision by teachers, application of regulations, schools' responses to fraud, other students' behavior and environmental conditions of perpetrators of fraud. Based on the opinion above, it can be seen that academic fraud behavior occurs not only due to individual factors but also due to environmental factors.

One theory related to fraud is the fraud pentagon theory. Fraud pentagon theory is the development and refinement of the two previous theories, the Fraud Triangle and the Fraud Diamon. This theory was introduced in literature in Sorunke [6] (2016) entitled "Personal Ethics and Fraudster Motivation: The Missing Link in Fraud Triangle and Fraud Diamond Theories". Sorunke (2016) in his research stated that important factors such as the personal ethics of fraud perpetrators are completely ignored in the fraud triangle and fraud diamond. Personal ethics help define people's core thinking; care, hate or just indifferent, so that comes the term fraud pentagon whose factors are similar to fraud diamond theory but added a variable of personal ethics in it so that there are five variables.

One of the factors that influence academic fraud is academic pressure. Academic pressure is a drive or motivation or goal to be achieved but is limited by the inability to achieve it, so that it can cause someone to commit fraud. Opportunity is also a factor that drives students to commit academic fraud. According to Albrecht et al. (2012: 34) [7] stated that the opportunity is a situation that allows someone to commit fraud that is considered safe by the perpetrators to cheat by assuming his fraudulent behavior will not be detected. Opportunities usually come from systems in the school environment that are not good, such as supervision in examinations that are not strict and sanctions given to students are too lenient.

Rationalization is also one of the factors that influence academic fraud. According to Albrecht et al. (2012: 34) [9] argues that rationalization is selfjustification or wrong reasons for a wrong behavior. The ability of individuals to cheat is also a factor that drives students to commit academic fraud. Wolfe \& Hermanson (2004) [8] argues that capabilities are personal traits and abilities that play a major role in committing academic fraud. Academic fraud perpetrators must have the ability to recognize opportunities and take advantage so that they can commit academic cheats continuously.

Personal ethics is the fifth factor affecting academic fraud. Personal ethics is a special form of ethics that refers to moral principles and rules that govern individual actions. Personal ethics is a system or ethical doctrine that has been chosen as a moral guide in a one's life (Sorunke, 2016). Personal ethics are the main driving factor in committing fraud. Personal ethics are values that help someone in determining the core thoughts of a person that is about individual love, hate or just indifferent (Sorunke, 2016).

In addition to the factors in fraud pentagon, researchers suspect the influence of academic procrastination factor on academic fraudulent behavior on students. Solomon \& Rothblum (1984) [9] suggested that academic procrastination is a tendency to delay in starting or completing tasks as a whole to do useless activities, so that performance is hampered, never completing tasks on time, and often late in attending meetings. Academic procrastination can trigger academic fraud behavior, for example students have the 
tendency to delay work or assignments given by the teacher. Though the task must be completed in accordance with a predetermined deadline. Students who like to postpone work will find it difficult to complete assignments on time, so when there is little time left, these students prefer to copy the answers of friends so that the process of completing the work is faster.

Previous research on academic fraud has been carried out much as research conducted by Becker et al. (2006) [10] which states that pressure, opportunity, and rationalization have a positive effect on academic fraud behavior. While research conducted by Primasari et al. (2017) [11] states that pressure and rationalization do not have a positive effect on academic fraud behavior while individual opportunity and ability have a positive effect on accounting students at Surakarta Private Universities.

The results of Murdiansyah et al. (2017) [12] research on Master of Accounting students of 20122014 Economics and Business Faculty Universitas Brawijaya shows that pressure, opportunity and rationalization have a positive effect on academic fraud behavior, but the ability to negatively influence academic fraud behavior. Malgwi \& Rakovski (2008) [13] in their research also stated that pressure, opportunity and rationalization factors had a positive and significant influence on academic fraud. While research conducted by Artani \& Wetra (2017) [14] explains that partially academic self-efficacy, pressure, opportunity, and rationalization variables have no effect on academic fraud behavior, but ability variables have a positive effect on accounting student cheating behavior at the University of Bali Province.

Other research also conducted by Irawan \& Setiyani (2017) [15] shows the results that pressure, opportunity, rationalization, and ability have a positive and significant effect on student academic fraud behavior, but personality ethics have a negative and significant effect on academic fraud behavior of accounting students at Semarang State University in 2016/2017 teaching. Research by Zaini et al., (2016) found that opportunity, rationalization and ability except pressure had no effect on academic fraud in accounting students. While greed and disclosure except the need to have a positive effect on academic fraud accounting students.

Research on the effect of academic procrastination on academic fraud has been conducted by Indah \& Shofiah (2012) [18] stating that the higher the academic procrastination conducted by students, the higher the academic dishonesty of students. Research by Khairat et al. (2014) [19] showed that academic procrastination has a significant positive effect on fraudulent behavior in high school students in Pesantren X. While research conducted by Warsiyah (2013) [22] shows that academic procrastination does not have a significant direct effect on the fraudulent behavior of IAIN Walisongo Tarbiyah Faculty students.

This study aims to determine the effect of academic pressure, opportunity, rationalization, the ability of individuals to commit fraud, personal ethics and academic procrastination on academic fraud of grade $\mathrm{X}$ IPS students of SMA Negeri 8 Semarang in 2018/2019 Academic Year.

\section{METHOD}

This type of research is quantitative research. The research design used is inferential research that analyzes the relationship between variables with hypothesis testing. The study population was students of Grade X IPS SMA Negeri 8 Semarang Academic Year 2018/2019, amounting to 180 students. Determination of the number of samples was carried out using the Slovin formula and obtained a sample of 125 students. The sampling technique used is proportional random sampling technique. Data collection techniques using a questionnaire or questionnaire. The variables in this study are academic fraud, academic pressure, demonstration, rationalization, the ability of individuals to commit fraud, personal ethics and academic procrastination. The method of data analysis uses descriptive analysis and multiple linear regression analysis.

\section{RESULTS AND DISCUSSION}

Based on the results of the descriptive analysis that has been done, the results of descriptive analysis are obtained regarding the variables of academic fraud, academic pressure, opportunity variables, rationalization variables, individual ability variables cheating, personal ethics variables and academic procrastination variables presented in Table 2 .

Table 2. Value of Academic Fraud Variables Descriptive Analysis

\begin{tabular}{llll}
\hline No & Variable & Average & Cathegory \\
\hline $\mathbf{1}$ & Academic Fraud & 39,18 & $\mathrm{RH}$ \\
$\mathbf{2}$ & Academic Pressure & 32,56 & $\mathrm{RH}$ \\
$\mathbf{3}$ & Opportunity & 54,10 & $\mathrm{RH}$ \\
$\mathbf{4}$ & Rationalization & 50,38 & $\mathrm{RH}$ \\
$\mathbf{5}$ & Individual ability & 51,40 & $\mathrm{RH}$ \\
& commit fraud & & \\
$\mathbf{6}$ & Personal ethics & 56,20 & $\mathrm{H}$ \\
$\mathbf{7}$ & Academic & 38,09 & $\mathrm{RH}$ \\
& Procrastination & & \\
\hline
\end{tabular}

Source : data analysis 2019

Based on Table 2. shows that the academic fraud variable, the academic pressure variable, the opportunity variable, the rationalization variable, the individual ability variable of cheating, and the academic procrastination variable are included in the rather high category, while the personal ethics variable is in the high category. The results of the descriptive analysis of 
the variables are then broken down into descriptive indicators. The details of each indicator of the academic fraud variable are presented in Table 3.

Table 3. Descriptive Analysis of Each Academic Fraud Variable Indicators

\begin{tabular}{|c|c|c|c|}
\hline No & Indicators & Average & Kategori \\
\hline 1 & $\begin{array}{l}\text { Plagiarism in } \\
\text { doing the } \\
\text { assignment }\end{array}$ & 7,36 & $\mathrm{RH}$ \\
\hline 2 & Data Manipulation & 3,09 & SR \\
\hline 3 & $\begin{array}{l}\text { Assignment } \\
\text { Replication }\end{array}$ & 9,23 & RH \\
\hline 4 & Exam Fraud & 10,43 & $\mathrm{R}$ \\
\hline 5 & Colluding & 9,06 & RH \\
\hline
\end{tabular}

Based on Table 3. shows that the academic fraud variable is measured using five indicators namely forgery in carrying out tasks with an average value of 7.36 in the rather high category, falsification of data with an average value of 3.09 including the very low category, doubling assignments with an average value of 9.23 in the rather high category, cheating at the time of testing with an average value of 10.43 in the low category, and wrong cooperation with an average value of 9.06 with a rather high category. Details of each indicator of academic pressure variables are presented in Table 4.

Table 4. Descriptive Analysis Per Indicator Academic Pressure Variable

\begin{tabular}{llll}
\hline No. & Indicator & Average & Category \\
\hline 1. & Fear of failure & 5,03 & $\mathrm{~L}$ \\
2. & $\begin{array}{l}\text { The pressure to satisfy } \\
\text { parent with high scores }\end{array}$ & 8,12 & $\mathrm{~L}$ \\
3. $\begin{array}{l}\text { Doing the assignment } \\
\text { without } 11,69\end{array}$ & $\mathrm{RH}$ \\
& $\begin{array}{l}\text { understanding since it is } \\
\text { too had or too easy }\end{array}$ \\
$\begin{array}{l}\text { Students competition for } \\
\text { the highest score }\end{array}$ & 7,72 & $\mathrm{~L}$ \\
\hline
\end{tabular}

Source: Data Analysis 2018

Based on Table 4. shows that the academic pressure variable is measured using four indicators namely fear of failure of 5.03 with a low category, pressure to satisfy parents of high scores included in the low category with an average value of 8.12 , work on assignment that are not understood because it is too difficult or too easy obtain an average value of 11.69 with a rather high category, and students compete for high scores obtained an average value of 7.72 with a low category. Details of each opportunity variable are presented in Table 5
Table 5.Descriptive Analysis on each of Opportunity Variable Indicators

\begin{tabular}{cllc}
\hline No & \multicolumn{1}{c}{ Indicator } & Average & Category \\
\hline $\mathbf{1}$ & $\begin{array}{l}\text { Lack of control to prevent } \\
\text { and detect any violation } \\
\text { of rules }\end{array}$ & 10,97 & $\mathrm{~L}$ \\
$\mathbf{2}$ & $\begin{array}{l}\text { Inability to assess the } \\
\text { quality of the task } \\
\text { outcome }\end{array}$ & $\mathrm{RH}$ \\
$\mathbf{3}$ & $\begin{array}{l}\text { Failure to discipline the } \\
\text { perpetrators of fraud }\end{array}$ & $\mathrm{L}$ \\
$\mathbf{4}$ & $\begin{array}{l}\text { Lack of access to } \\
\text { information }\end{array}$ & $\mathrm{RH}$ \\
$\mathbf{5}$ & $\begin{array}{l}\text { Ignorance, apathy and the } \\
\text { inability of the injured } \\
\text { party }\end{array}$ & $\mathrm{RH}$ \\
$\mathbf{6}$ & Lack of inspection & 8,78 & $\mathrm{RH}$ \\
\hline $\mathrm{Sou}$
\end{tabular}

Source: Research Data Analysis 2019

Based on Table 5. shows that the opportunity variable is measured using 6 indicators namely lack of control to prevent and detect violations of 10.97 with a low category, the inability to assess the quality of an overall result obtained an average value of 8.53 with a rather high category, failure in disciplining fraud perpetrators as a whole obtained an average value of 8.30 with a low category, lack of overall access to information obtained an average value of 8.64 in the category of rather high, ignorance, apathy and the inability of the injured party overall obtained an average value of 8.88 with a rather high category, the overall lack of inspection obtained an average value of 8.78 in the rather high category. The details of each indicator of rationalization variable are presented in Table 6.

Table 6.Descriptive Analysis on each of Rationalization Variable Indicators

\begin{tabular}{clcc}
\hline No. & \multicolumn{1}{c}{ Indicators } & Average & Category \\
\hline 1. & $\begin{array}{l}\text { The Academic Fraud is } \\
\text { Often Conducted }\end{array}$ & 12 & RH
\end{tabular}

2. The Perpetrator only 9,54 RH committed the academic fraud in desperate situation

3. Unfair treatment from 9,11

$\mathrm{RH}$ school

4. No victim 8,31

5. The fraud is commited 11,42 $\mathrm{L}$ for good cause

Source : Data Analysis 2019

Based on Table 6 . shows that the rationalization variable is measured using five indicators namely academic fraud indicators are often done at 12 with a 
rather high category, actors only commit academic fraud in an overall urgency state obtained an average value of 9.54 with a rather high category, treatment unfair of the school as a whole an average grade of 9.11 was obtained with a rather high category, none of the aggrieved parties as a whole gained an average grade of 8.31 with a low category, cheating was done for a good purpose as a whole an average of 11.40 with a low category. The details of each indicator of an individual's ability to commit fraud are presented in Table 7 .

Table7.Descriptive Analysis on each of Individual's Ability to Commit Fraud Variable Indicators.

\begin{tabular}{ccccc}
\hline No & \multicolumn{1}{c}{ Indicators } & Average & Category \\
\hline $\mathbf{1}$ & $\begin{array}{c}\text { Able to commit fraud } \\
\text { based on the available }\end{array}$ & & $\mathrm{RH}$ \\
& $\begin{array}{l}\text { opportunity } \\
\mathbf{2}\end{array}$ & $\begin{array}{l}\text { Having a high confidence } \\
\mathbf{3}\end{array}$ & $\begin{array}{l}\text { Able to influence other } \\
\text { students to coomit fraud }\end{array}$ & \\
$\mathbf{4}$ & $\begin{array}{l}\text { Able to lie and able to } \\
\text { supress the guilty feeling } \\
\text { after committing the } \\
\text { fraud. }\end{array}$ & $\mathrm{LH}$ \\
\end{tabular}

Source : Research data analysis 2019

Based on Table 7. shows that the ability of individuals to commit fraud variable is measured using four indicators, namely being able to commit fraud based on the opportunities of 14.87 with a rather high category, having a strong sense of confidence overall obtained an average value of 11.45 with low category, can influence other students to commit cheating as a whole an average score of 13.05 with a rather high category, can lie and suppress guilt after cheating as a whole obtained an average value of 12.03 with rather high category. Details of each indicator of personal ethics variables are presented in Table 8 .

Table 8. Descriptive Analysis on each of Personal Ethics Variable Indicators

\begin{tabular}{clll}
\hline No. & \multicolumn{1}{c}{ Indicators } & Average & Category \\
\hline 1. & Integrity & 6,63 & $\mathrm{RH}$ \\
2. & Credibility & 10,32 & $\mathrm{RH}$ \\
& & 10,2 & $\mathrm{RH}$ \\
3. & Sense of justice & 9,79 & $\mathrm{RH}$ \\
4. & Transparency & 7,26 & $\mathrm{RH}$ \\
5. & Cautious & 12 & $\mathrm{~T}$ \\
$\mathbf{6 .}$ & Simplicity &
\end{tabular}

Sumber : Olah data penelitian 2019

Based on Table 8. shows that the personal ethics variable is measured using six indicators namely integrity indicator of 6.63 with a rather high category, credibility is obtained an average value of 10.32 with a rather high category, overall fairness is obtained an average value of 10,20 with a rather high category, overall transparency obtained an average value of 9.79 with a rather high category, caution obtained an average value of 7.26 with a rather high category, overall simplicity obtained an average value of 12 with a high category. Details of each indicator of academic procrastination variables are presented in Table 9.

Table 9. Descriptive Analysis on each of Academic Procrastination Variable Indicators

\begin{tabular}{llll}
\hline No & \multicolumn{1}{c}{ Indicator } & $\begin{array}{l}\text { Rata- } \\
\text { Rata }\end{array}$ & Category \\
\hline 1. $\begin{array}{l}\text { There is a delay in starting } \\
\text { and finishing the } \\
\text { assignment }\end{array}$ & $\mathrm{RH}$ \\
2. The delay in doing the 9,09 & $\mathrm{RH}$ \\
$\begin{array}{l}\text { assignment } \\
\text { Thye time disparity } \\
\text { between plan and actual } \\
\text { performance in completing } \\
\text { the assignment. } \\
\text { The tendency to do other } \\
\text { entertaiiment activity }\end{array}$ & $\mathrm{RH}$ \\
\hline
\end{tabular}

Sumber : Olah data penelitian 2019

Based on Table 9. shows that the academic procrastination variable is measured using four indicators namely the delay in starting and completing assignments by 13 with a fairly high category. there is a delay in doing the task obtained an average value of 9.09 with the category rather high, there is a time gap between the plan and the actual performance in completing the assignment as a whole an average value of 9.48 with a rather high category, there is a tendency to do other entertainment activities obtained an average value of 6.52 with a rather high category.

Prior to the multiple linear regression analysis, the prerequisite tests include the normality and linearity tests as well as the gradeical assumption tests including multicollinearity and heterocedasticity tests.

Test for normality through the KolmogorovSmirnov test, a value of 0.773 and a significance of 0.588 was obtained. Because the significance value> 0.05 , it can be concluded that the residual data are normally distributed. In the linearity test of academic pressure, opportunity, rationalization, the ability of individuals to commit fraud, personal ethics and academic procrastination against academic fraud students have a significance of $<0.05$ so that it can be said that the data obtained are linear.

The results of multiple regression analysis using the help of the IBM SPSS Statistics 21 program obtained the multiple linear regression equation as follows.

$$
\mathrm{Y}=25,326+0,395 \mathrm{X} 1-0,133 \mathrm{X} 2-0,017 \mathrm{X} 3
$$

$+0,174 \mathrm{X} 4-0,124 \mathrm{X} 5+0,186 \mathrm{X} 6+\mathrm{e}$

Based on the multicollinearity test results obtained significance value of each independent variable has a tolerance value $>0.1$ and VIF $<10$. This shows that in this study multicollinearity did not occur. Based on the 
results of the heteroscedasticity test using the glacier test the significance value of the independent variables (academic pressure, opportunity, rationalization, the ability of individuals to commit fraud, personal ethics, and academic procrastination) was more than 0.05 . So it can be concluded that the regression model in this study did not occur heteroscedasticity.

Effects of Fraud Pentagon Dimension and Academic Procrastination on Student Academic Fraud

Simultaneous Significance Test was tested for the first hypothesis (H1), this test is used to find out whether all independent variables (academic pressure, opportunity, rationalization, the ability of individuals to commit fraud, personal ethics and academic procrastination have the same effect on the academic fraud variable. Using the $\mathrm{F}$ Test. If the simultaneous significance values are presented in Table 10.

Table 10. Simultaneous Test Results ( F-Test) ANOVA ${ }^{a}$

\begin{tabular}{|l|l|l|l|l|l|}
\hline Model & $\begin{array}{l}\text { Sum of } \\
\text { Squares }\end{array}$ & df & $\begin{array}{l}\text { Mean } \\
\text { Square }\end{array}$ & F & Sig. \\
\hline 1 Regression & 2120,165 & 6 & 353,361 & 14,967 &, $000^{\mathrm{b}}$ \\
\hline $\begin{array}{l}\text { Residual } \\
\text { Rotal }\end{array}$ & 2785,963 & 118 & 23,610 & & \\
\hline
\end{tabular}

a. Dependent Variable: Y

b. Predictors: (Constant), X6, X2, X5, X1, X4, X3

Source: research Data Analysis 2019.

Based on Table 10. it is known that the results of the F statistical test obtained a significance value of $0,000<0.05$, therefore $\mathrm{H} 1$ is accepted. So it can be said that together or simultaneously there is an influence between academic pressure, opportunity, rationalization, the ability of individuals to commit fraud, personal ethics and academic procrastination on academic fraud. Furthermore, the simultaneous determination coefficient test is used to measure how far the ability of academic pressure variables, opportunities, rationalization, the ability of individuals to commit fraud, personal ethics and academic procrastination in explaining the variation of academic fraud variables. The results of the simultaneous determination coefficient test can be seen in Table 11 .

Table 11. Results of The results of the simultaneous determination coefficient test

Source: Research Data Analysis 2019

Based on the results of the simultaneous determination coefficient R2 test in Table 11. Obtained an adjusted R2 value of 0.403 . The figure shows that the variable of academic fraud can be explained by academic pressure, opportunity, rationalization, individual ability to commit fraud, personal ethics and academic procrastination by $40.3 \%$. This means that the higher the academic pressure, opportunity, rationalization, individual ability to commit fraud, personal ethics (fraud pentagon) and academic procrastination, the higher the academic fraud of Grade X IPS students of SMA Negeri 8 Semarang 2018/2019

\section{Model Summary}

\begin{tabular}{|l|l|l|l|r|}
\hline Model & $\mathrm{R}$ & $\begin{array}{l}\mathrm{R} \\
\text { Square }\end{array}$ & $\begin{array}{l}\text { Adjusted R } \\
\text { Square }\end{array}$ & $\begin{array}{l}\text { Std. Error of } \\
\text { the Estimate }\end{array}$ \\
\hline 1 &, $657^{\mathrm{a}}$ &, 432 &, 403 & 4,859 \\
\hline
\end{tabular}

Academic Year.

The results of this study are consistent with fraud pentagon theory which states that academic fraud is influenced by academic pressure, opportunity, rationalization, the ability of individuals to commit fraud and personal ethics. Someone who has high academic pressure, opportunities are wide open, rationalization, individual ability to commit fraud, low personal ethics and the attitude of someone who likes to procrastinate to start and complete assignments can encourage students to commit academic fraud. The results of this study are also in accordance with Cognitive theory and Cognitive Behavioral, if students feel unable to complete their tasks optimally and feel afraid of failure, then students will tend to procrastinate in completing their assignments. Though the task must be completed in accordance with a predetermined deadline. Students who like to postpone work will find it difficult to complete assignments on time, so when there is time left, these students prefer to copy the answers of friends. This will cause academic fraud. The more students do academic procrastination, the higher the academic fraud behavior that will occur.

The research data obtained based on the results of descriptive analysis is known that the academic fraud of students of grade X IPS SMA Negeri 8 Semarang in the 2018/2019 Academic Year is in the rather high category as seen from the average of 39.18 .

The results of this study are in line with previous studies put forward by Irawan \& Setiyani (2017) stating that pressure, opportunity, rationalization, ability and personal ethics influence the academic fraud behavior of accounting students of Semarang State University 2016/2017 Academic Year. In addition, this study is also in line with research conducted by Khairat et al. (2014) [16] and Indah \& Shofiah 2012) [17] which states that academic procrastination influences academic fraud behavior.

Positive Influence of Academic Pressure on Student Academic Fraud

The t-test basically shows how far the influence of explanatory variables or independent variables individually in explaining the dependent variables. Partial significance test is used to test the 
second hypothesis ( $\mathrm{H} 2)$, third hypothesis $(\mathrm{H} 3)$, fourth hypothesis (H4), fifth hypothesis (H5), sixth hypothesis (H6) and seventh hypothesis (H7). Partial test in this case is done by comparing the significance value of the count with a significance of 0.05 . If the significance calculation shows the value $<0.05$ then Ho is rejected and $\mathrm{Ha}$ is accepted, which means that each independent variable influences the dependent variable. The t test is presented in Table 12.

Table12.

\section{t-test results}

Coefficients $^{\mathrm{a}}$

\begin{tabular}{|c|c|c|c|c|c|}
\hline \multirow[t]{2}{*}{ Model } & \multicolumn{2}{|c|}{$\begin{array}{l}\text { Unstandardized } \\
\text { Coefficients }\end{array}$} & $\begin{array}{l}\text { Standardized } \\
\text { Coefficients }\end{array}$ & \multirow[t]{2}{*}{$\mathrm{t}$} & \multirow[t]{2}{*}{ Sig. } \\
\hline & B & $\begin{array}{l}\text { Std. } \\
\text { Error }\end{array}$ & Beta & & \\
\hline (Constant) & 25,326 & 6,253 & & 4,051 & ,000 \\
\hline $\mathrm{X} 1$ & ,395 & ,085 & ,411 & 4,671 & 000 \\
\hline $\mathrm{X} 2$ &,- 133 & ,065 &,- 196 & 2,038 & ,044 \\
\hline $1 \mathrm{X} 3$ &,- 017 & ,074 &,- 028 &,- 233 & ,816 \\
\hline X4 &, 174 & 074 & ,270 & 2,339 & 021 \\
\hline $\mathrm{X} 5$ &,- 124 & ,059 &,- 171 & 2,125 & ,036 \\
\hline X6 & 186 & ,088 &, 160 & 2,120 &, 036 \\
\hline
\end{tabular}

a. Dependent Variable: Y

Source: Reseach Result dara 2019

The results of the t test in Table 12 obtained significance results of 0,000 less than 0.05 , which means that $\mathrm{H} 2$ is a positive influence of academic pressure on academic fraud of grade X IPS students of SMA Negeri 8 Semarang in 2018/2019 Academic Year, the hypothesis is accepted. This means that the greater the academic pressure students have, the higher the level of academic fraud that students will commit.

The magnitude of the effect of each independent variable on the dependent variable is known from the magnitude of the coefficient of partial determination ( $\mathrm{r} 2)$ of each variable. The results of the partial determination coefficient test are explained in table 13.

Table 13.

The results of partial determination coefficient test $\left(\mathbf{r}^{2}\right)$

\section{Coefficients ${ }^{\mathrm{a}}$}

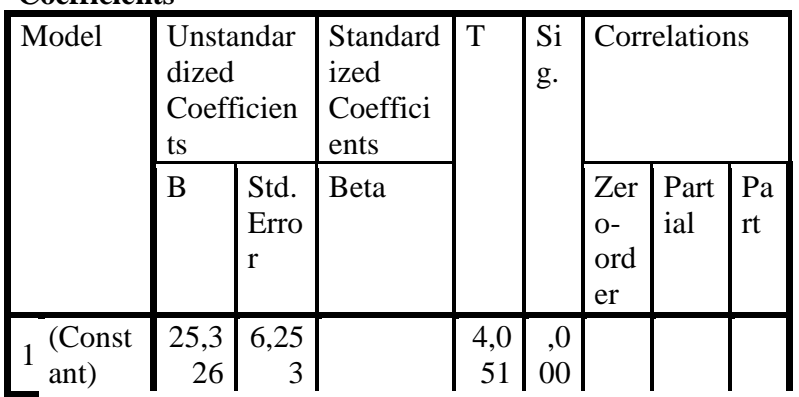

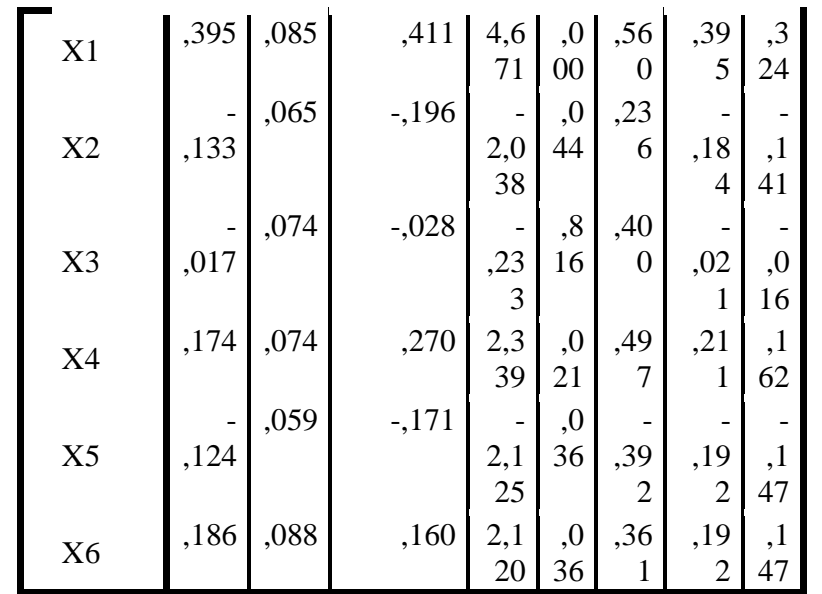

a. Dependent Variable: Y

Source: Research data analysis 2019

In Table 13. you can see the partial determination coefficient value for the academic pressure variable for academic fraud by 0.395 . This value is then squared and presented to be $15.60 \%$. This shows that partially the academic pressure variable influences and contributes to academic fraud by $15.60 \%$

The results of this study are consistent with fraud pentagon theory, which states that academic pressure influences academic fraud. Where academic pressure in this study as a motivating factor for students to commit academic fraud in order to get good grades. The higher the pressure that is received by someone then there is a high probability that someone is committing fraud. When students receive great pressure and these students have low ability, then these students will do everything they can to achieve their goals so that they can be realized, one of them by committing fraud. The data obtained based on descriptive analysis is known that the academic pressure possessed by students of grade X IPS SMA Negeri 8 Semarang in the 2018/2019 Academic Year is in the rather high category, seen an average of 32.56. Academic pressure variable is measured using four indicators, namely indicators of fear of failure included in the low category with an average value of 5.03, an indicator of pressure to satisfy parents of a high value with an average value of 8.12 indicates a low category, an indicator work on assignments that are not understood because they are too difficult or too easy with an average score of 11.69 in the rather high category and indicators of student competency will be of high value with an average value of 7.72 in the low category. It can be concluded that from the four indicators can explain that the level of academic fraud caused by academic pressure is quite high.

The results show that academic pressure has a corresponding influence on the initial hypothesis due to the higher academic pressure received by someone, there is a high probability that someone is committing 
fraud, it is also in accordance with the theory of fraud triangle, diamond fraud and fraud pentagon.

The results of this study are in line with the research proposed by Becker et al. (2006) [21] which states that pressure has a positive influence on the occurrence of academic fraud and states that cheating will arise along with the pressure felt by students. This study is in line with that conducted by Murdiansyah et al. (2017) [22] which shows that there is a positive influence of academic pressure on academic fraud behavior.

\section{Student Academic Fraud \\ Positive Influence of Opportunities on}

The results of the $t$ test in Table 12. show that the calculated value of the opportunity variable for academic fraud is -2.038 with a significance value of 0.044 . The significance value of the opportunity variable was $0.044<0.05$ with a t-test value of $-2.038>$ ttable of 1.658 , which means that $\mathrm{H} 3$ had no positive influence on the opportunity for academic fraud in grade X IPS students of SMA Negeri 8 Semarang in 2018/2019 Academic Year, the hypothesis was rejected. This means that the higher the chance of cheating, the lower the level of academic fraud that students will commit.

Based on Table 13. you can see the partial determination coefficient value for the opportunity variable of -0.184 . This value is then squared and presented to be $3.39 \%$. This shows that partially the opportunity variable influences and contributes to academic fraud by $3.39 \%$.

The results of this study contradict the theoretical basis used, namely the fraud pentagon dimension theory. In this theory revealed that one of the factors driving someone to commit fraud is because of the perceived opportunity. If the chance of cheating is high, the higher a person is in academic fraud. Whereas in this study explained that the higher the opportunities felt by students, the lower the academic fraud that occurs. Thus, the fraud pentagon dimension theory cannot verify the effect of opportunity on academic fraud.

But the results of these studies can be explained using social cognitive theory. According to Bandura in Fadri \& Khafid (2018) [17] explains that when a person behaves in a certain way and observes how the environment reacts, one begins to distinguish between desirable responses and unwanted responses. When students have a high chance of committing academic fraud then the student develops an understanding of which responses are appropriate and which are not appropriate such as assuming that committing an academic fraud is an act that will be detrimental to himself, then the student will not cheating even though he has a great opportunity to do it. Because humans have the capacity to control the nature and quality of their lives.
The data obtained based on descriptive analysis found that the opportunity to commit academic fraud in grade X IPS of SMA Negeri 8 Semarang in the 2018/2019 Academic Year was in the rather high category as seen from an average of 54.10. Furthermore, from the results of the descriptive analysis there are several indicators that show a low category, namely the lack of control indicators to detect violations with an average value of 10.97 and failure to discipline the perpetrators of fraud with an average of 8.30. It can be concluded that there are some indicators in the low category that cause academic fraud owned by students is also low, so it is suspected that there are other factors that cause this. Another contributing factor is that because students are afraid of the threat of teachers who will not give a value if caught cheating, students cannot choose their own seats during the exam and during the exam supervising the strict exam. So students need to consider when committing academic fraud despite having high opportunities.

The results of this study are in line with previous studies conducted by Zaini et al., (2016) []; Apriani et al., (2017) [18]. Research conducted by Zaini et al (2016) [26] results of the study explained that the opportunity has a negative coefficient and is not significant so that the opportunity does not affect the academic fraud of accounting students.

Research conducted by Apriani et al., (2017) of 85 respondents in undergraduate accounting students at Ganesha University of Education on student academic fraud, explains that the opportunity variable has a negative coefficient and is insignificant so that opportunity does not affect academic fraud behavior in accounting students $\mathrm{S} 1$ The research explains that if there is a good control system and there are strict sanctions in following up on the cheating behavior then there is no chance to commit fraud.

But there are results of previous studies that are not in harmony with this study, namely research that has been done by Becker et al. (2006); Rangkuti (2011) [19]; and Murdiansyah et al., (2017) . The results of these studies reveal that opportunity positively influences academic fraud.

Positive Influence of Individual Skills for Fraud on Student Academic Fraud

The results of the t test in Table 12. show that the calculated value of the individual ability variable cheating against academic fraud was 2.333 with a significance value of 0.021 . Significance value of the variable ability of individuals cheating $0.021<0.05$ with a tcount of 2.333> ttable of 1.658 which means that $\mathrm{H} 5$ there is a positive influence on the ability of individuals to commit cheating on academic fraud in grade X IPS SMA Negeri 8 Semarang 2018/2019 Academic Year stated hypothesis be accepted. This means that the higher the individual's ability to commit 
fraud students have, the higher the possibility of academic fraud by students.

Based on Table 13. it can be seen the value of the partial determination coefficient for the variable ability of individuals to commit cheating on academic fraud by 0.211 . This value is then squared and presented to $4.45 \%$. This shows that partially the ability of individuals to commit fraud influences and contributes to academic fraud by $4.45 \%$.

The results of this study can verify the theory used is the fraud pentagon theory. Where the variable ability possessed by the perpetrators of fraud encourages someone to commit fraud. A student will not commit academic fraud if he does not have sufficient ability to commit fraud. The higher the academic fraud ability possessed by students, the higher the academic fraud that will occur.

The data obtained based on descriptive analysis is known that the ability of individuals to commit cheating students in grade $X$ IPS of SMA Negeri 8 Semarang in the 2018/2019 Academic Year is in the quite high category as seen from an average of 51.40. Meanwhile, for the results of the descriptive analysis of each indicator it is known that the indicator can commit fraud based on the opportunities that are included in the rather high category with an average of 14.87, the indicator has a strong confidence with an average of 11.45 included in the low category, the indicator can influence other students to commit cheating with an average of 13.04 indicating the category is quite high and the indicator can lie and suppress guilt with an average of 12.03 included in the low category. It can be concluded that from the four indicators can explain that the level of academic fraud caused by the ability of individuals to commit fraud is quite high.

The results show that the ability of individuals to commit fraud has an appropriate direction of influence on the initial hypothesis because the higher the ability of individuals to commit fraud owned by someone, there is a possibility that the higher the person is committing fraud, this is in accordance with the diamond fraud theory.

The results of this study are in line with research conducted by Artani \& Wetra (2017) showing that ability has a positive effect on academic fraud behavior. In line with the study, research conducted by Irawan \& Setiyani (2017) states that ability has a positive influence on student academic fraud behavior.

The Negative Effect of Personal Ethics on Student Academic Fraud

The results of the $t$ test in Table 12. show that the value of the t-value of the personal ethics variable against academic fraud is $-2,125$ with a significance value of 0.036 . The significance value of the personal ethics variable $0.036<0.05$ with a t-count of $-2.125>$ ttable of 1.658 which means that $\mathrm{H} 6$ there is a negative influence of personal ethics on academic fraud of grade X IPS students of SMA Negeri 8 Semarang 2018/2019 Academic Year declared acceptable. This is that the higher the students have personal ethics, the more likely they will not be cheating. While students who have low personal ethics will most likely commit fraud.

Based on Table 13. seen the value of the partial determination coefficient for personal ethics variables against academic fraud of 0.192 . This value is then squared and presented to be $3.69 \%$. This shows that partially personal ethics variables affect and contribute to academic fraud by $3.69 \%$.

The results of this study are consistent with Pentagon's fraud theory proposed by Sorunke (2016) [30] explaining that in addition to academic pressure, opportunity, rationalization, and the ability of individuals to commit fraud, the variable that is highly influential on fraud is personal ethics. In the pentagon theory of fraud states that personal ethics is the main driving factor in committing fraud. Personal ethics are rules that exist in society when someone has a sense of caring for the community, then someone will take action according to the rules that apply in society. They realize that rules are made to be implemented not to be broken. So students who have high personal ethics will most likely not commit fraud even when in a state of dire need. While students who have low personal ethics will most likely commit fraud.

The data obtained based on descriptive analysis is known that the personal ethics of students of Grade X IPS SMA Negeri 8 Semarang in 2018/2019 Academic Year are in the high category seen from an average of 56.20. Meanwhile, for the results of the descriptive analysis of each indicator namely integrity indicators included in the category of quite high with an average of 6.63 , an indicator of credibility with an average of 10.32 included in the category of quite high, an indicator of fairness with an average of 10.20 indicates a rather high category, the fourth indicator of transparency obtains an average of 9.79 included in the rather high category, a caution indicator with an average of 7.26 included in the rather high category and an indicator of simplicity included in the high category with an average of 12 . It can be concluded that from the six indicators can explain that the level of academic fraud caused by personal ethics is high.

The results show that personal ethics have a negative effect on academic fraud. This is because when students have high personal ethics they are able to think more rationally that cheating is against the rules and detrimental to various parties so students will not do academic disability even though in circumstances they have academic pressure, opportunity, rationalization, even the ability of individuals to commit fraud. So it can be concluded that the results of this study are in accordance with fraud pentagon theory. 
The results of this study are also in line with research conducted by Sorunke (2016) [31]; Irawan \& Setiyani (2017) [32]. Sorunke (2016) [33] said that 83\% of respondents agreed that someone with low personal ethics had a higher tendency / motivation to commit fraud than someone with higher personal ethics. As many as $68 \%$ of respondents agreed that personal ethics is a strong variable in influencing fraud. Research conducted by Irawan \& Setiyani (2017) [34] shows that personal ethics negatively affect academic fraud behavior.

Positive Effect of Academic Procrastination on Student Academic fraud

The results of the $t$ test in Table 13. show that the calculated value of the academic procrastination variable against academic fraud is 2.120 with a significance value of 0.036 . Significance value of the variable ability of individuals cheating $0.036<0.05$ with a tcount of 2.120> t-table of 1.658 which means that $\mathrm{H} 7$ there is a positive influence of academic procrastination on academic fraud of grade X IPS students of SMA Negeri 8 Semarang 2018/2019 Academic Year. This means that the higher the academic procrastination, the higher the academic fraud the student has.

Based on Table 13. you can see the partial determination coefficient value for the academic procrastination variable for academic fraud by 0.192 . This value is then squared and presented to be $3.69 \%$. This shows that partially academic procrastination variables affect and contribute to academic fraud by $3.69 \%$.

The results of this study are in accordance with the behavioral-cognitive theory described by Ellis \&Knaus (2002) [35] in (Tuckman 2002) [20]. This theory explains that if students feel unable to complete their tasks optimally and feel afraid of failure, students will tend to procrastinate in completing their assignments. Though the task must be completed in accordance with a predetermined deadline. Students who like to postpone work will find it difficult to complete assignments on time, so when there is time left, these students prefer to copy the answers of friends. This will cause academic fraud. The more students do academic procrastination, the higher the academic fraud behavior that will occur.

Data obtained based on descriptive analysis found that academic procrastination owned by Social Sciences grade X students of SMA Negeri 8 Semarang in 2018/2019 Academic Year was in the rather high category as seen from the average of 38.09. Meanwhile, for the results of the descriptive analysis of each indicator it is known that the indicator of delay in starting and completing tasks with an average of 13 is included in the rather high category, the second indicator of delays in doing the task with an average of 9.09 shows the sufficient category high, the third indicator is the time gap between plans and actual performance in completing tasks with an average of 9.48 included in the category of rather high and an indicator of the tendency to carry out other activities that are entertainment included in the category of rather high with an average of 618 . It can be concluded that from the four indicators can explain that the level of academic fraud caused by academic procrastination is quite high.

The results show that academic procrastination has an appropriate direction of influence on the initial hypothesis because the higher the academic procrastination owned by someone, the higher the person is committing fraud, it is also in accordance with behavioral-cognitive theory.

The results of this study are in line with research conducted by Khairat et al. (2014) [37] showing that academic procrastination has a significant positive effect on cheating behavior in high school students in Pesantren X. In line with research conducted by Indah \& Shofiah (2012), there is an influence academic procrastination of student academic dishonesty.

\section{CONCLUSION}

Based on the results of research and discussion about the influence of the of fraud pentagon dimensions and academic procrastination on academic fraud in grade X IPS students of SMA Negeri 8 Semarang in the 2018/2019 Academic Year as follows: (1) There is a positive influence of the dimensions of fraud pentagon and academic procrastination on academic fraud in grade X IPS students at SMA Negeri 8 Semarang by $40.3 \%$ (2) There is a positive influence of academic pressure on academic fraud in grade $\mathrm{X}$ students of Social Sciences at SMA Negeri 8 Semarang partially at $15.60 \%$ (3) There is no positive influence on opportunities for student academic fraud grade X IPS SMA Negeri 8 Semarang (4) There is no positive effect of rationalization on academic fraud students of grade $X$ IPS SMA Negeri 8 Semarang (5) There is a positive influence on the ability of individuals to cheat on academic fraud students of grade X IPS SMA Negeri 8 Semarang partially by $4.45 \%$ (6) There is a negative influence of personal ethics on Partial academic fraud of IPS grade X SMA Negeri 8 Semarang 2019 partially by $3.69 \%$ (7) There is an influence of academic procrastination on academic fraud of grade X IPS SMA Negeri 8 Semarang partially by $3.69 \%$. The advice given related to the results of this study is to create conditions that do not make students depressed such as not giving too many assignments and accustoming students to discipline, increasing supervision and examination and applying stricter rules related to work on assignments and examinations. In addition, students 
should increase their confidence or confidence in their academic abilities so as to minimize academic fraud.

\section{REFFERENCES}

[7] Albrecht, W. S., Albrecht, C. O., Albrecht, C. C., \& Zimbelman, M. F. (2012). Fraud Examination.

[18] Apriani, N., Sujana, E., \& Sulindawati, I. G. E. (2017). Pengaruh Pressure, Opportunity, dan Rationalization Terhadap Perilaku Kecurangan Akademik (Studi Empiris : Mahasiswa Akuntansi Program S1 Universitas Pendidikan Ganesha. EJournal S1 Ak Universitas Pendidikan Ganesha, $7(1)$.

[14] Artani, K. T. B., \& Wetra, I. W. (2017). Pengaruh Academic Self Efficacy Dan Fraud Diamond Terhadap Perilaku Kecurangan Akademik Mahasiswa Akuntansi Di Bali. Jurnal Riset Akuntansi, 7(2), 123-132.

Banjarmasin tribunnews. (2018). Sadis, Terbukti Mencontek Saat Ujian, 500.000 Siswa di India Dikeluarkan. Diakses pada tanggal 03 Juni 2018 pada alamat web:http://banjarmasin.tribunnews.com/2018/02/ 08/sadis-terbukti mencontek-saat-ujian-500000siswa-di-india-dikeluarkan.

[10] Becker, D., Connolly, J., Lentz, P., \& Morrison, J. (2006). Using The Business Fraud Triangle To Predict Academic Dishonesty Among Business Students. Academy of Educational Leadership Journal, 10(1), 37-54.

[17] Fadri, N., \& Khafid, M. (2018). Peran Kecerdasan Spiritual Memoderasi Pengaruh Dimensi fraud Diamond Dan SelF-Efficacy Terhadap Kecurangan Akademik. Economic Education Analysis Journal, 1-19.

[17] Indah, P. S., \& Shofiah, V. (2012). Hubungan Prokrastinasi Akademik Dengan Ketidakjujuran Akademik Pada Mahasiswa Psikologi UIN Suska Riau. Jurnal Psikologi, 8(1).

[15] Irawan, M., \& Setiyani, R. (2017). Pengaruh Fraud Pentagon Terhadap Perilaku Kecurangan Akademik Mahasiswa Pendidikan Akuntansi UNNES. Economic Education Analysis Journal, $3(1), 1-16$.

[1] Kementrian Pendidikan Nasional. (2011). Panduan Pelaksanaan Pendidikan Karakter. Jakarta: Badan Penelitian dan Pengembangan Pusat Kurikulum dan Pembukuan.
[16] Khairat, U., Maputra, Y., \& Rahmi, F. (2014). Pengaruh prokrastinasi akademik terhadap perilaku menyontek pada siswi sma di pesantren x. RAP UNP, 5(2), 192-203.

[13] Malgwi, C. A., \& Rakovski, C. (2008). Behavioral Implications of Evaluating Determinants of Academic Fraud Risk Factors. Journal of Forensic \& Investigative Accounting, 1(2), 1-37.

[12] Murdiansyah, I., Sudarma, M., \& Nurkholis. (2017). Pengaruh Dimensi Fraud Diamond Terhadap Perilaku Kecurangan Akademik (Studi Empiris pada Mahasiswa Magister Akuntansi Universitas Brawijaya. Jurnal Akuntansi Aktual, 4(2), 121-133.

[5] Matindas, R. (2010). Mencegah Kecurangan Akademik. http://budimatindas.blogspot.com/2010/08/menc egah-kecurangan-akademik.html (Diakses pada 11 Januari 2019).

[11] Primasari, D. N., Suhendro, \& Endang Masitoh W. (2017). Perilaku Kecurangan Akademik Mahasiswa Akuntansi Dengan Menggunakan Dimensi Fraud Diamond. Jurnal Akuntansi Dan Sistem Teknologi Informasi, 13(April), 118-126.

[19] Rangkuti, A. A. (2011). Opportunity as A Threat to Academic Integrity. Jounal of Education, 4(1), 31-36.

Republika.co.id. (2019). Laporan Kecurangan UN 2019.

https://infografis.republika.co.id/berita/infografis Inasionalinfografis/prd1vb384/laporankecurangan-un-2019. (Diakses pada tanggan 14 Mei 2019).

[2] Saidina, D. A., Hj. Nurhidayati, \& Mawardi, M. C. (2016). Faktor-Faktor Yang Mempengaruhi Perilaku Kecurangan Akademik Dalam Perspektif Fraud Triangle Pada Mahasiswa Akuntansi Universitas Islam Malang, 1-14

[9] Solomon, L. J., \& Rothblum, E. D. (1984) Academic Procrastination: Frequency and Cognitive-Behavioral Correlates. Journal of Counseling Psychology, 31(4), 503-509.

[6] Sorunke. (2016). Personal Ethics and Fraudster Motivation: The Missing Link in Fraud Triangle and Fraud Diamond Theories. International Journal of Academic Research in Business and Social Sciences, 6(2), 159-165. 
https://doi.org/10.6007/IJARBSS/v6-i2/2020.

[20] Tuckman, B. W. (2002). APA Syimposium Paper,Chicago 2002 Academic Procrastinators: Their Rationalizations and Web- Course Perfomance dalam http://all.succescenterohio.state.edu/reference/procrastinator_ APA_paper.htm.

[3] Utami, F. (2014). Perilaku Mencontek Ditinjau Dari Ekspektasi Kesuksesan dan Prokrastinasi Akademik Siswa. Naskah Publikasi.

[22]Warsiyah. (2013). Pengaruh Tingkat Keimanan, Prokrastinasi Akademik dan Sikap terhadap Menyontek pada Perilaku Menyontek Mahasiswa Fakultas Tarbiyah IAIN Walisongo. IAIN Walisongo Semarang.

[4] Wisnumurti, P. A., \& Yulianto, A. (2017). Pengaruh Dimensi Fraud Diamond dan Prokrastinasi Akademik Terhadap Kecurangan Akademik Siswa Kelas X dan XI Kompetensi Keahlian Akuntansi di SMK Negeri 2 Tegal Tahun 2016/2017. Economic Education Analysis Journal, 1-16.

[8]Wolfe, D. T., \& Hermanson, D. R. (2004). The Fraud Diamond: Considering the Four Elements of Fraud. 7/9/13 The Fraud Diamond: Considering the Four Elements of Fraud, 12, 3842.

[21] Yudiana, A. P., \& Lastanti, H. S. (2016). Analisis Pengaruh Dimensi Fraud Diamond Terhadap Perilaku Kecurangan Akademik Mahasiswa Fakultas Ekonomi. Seminar Nasional Dan Call Paper Fakultas Ekonomi UNIBA Surakarta, 412422. 